\title{
ELEOCHARIS OBTUSETRIGONA (CYPERACEAE) NEW TO NORTH AND CENTRAL AMERICA
}

\author{
M. SOCORRO GONZÁLEZ-ELIZONDO \\ MARTHA GonZÁLEZ-ELIZONDO \\ CIIDIR Unidad Durango \\ Instituto Politécnico Nacional \\ Apartado postal 738 \\ 34000 Durango, Dgo., México \\ and \\ S. GALEN SMITH \\ Department of Biology \\ University of Wisconsin-Whitewater \\ 53190 Whitewater, Wisconsin, U.S.A
}

\begin{abstract}
Eleocharis obtusetrigona (Lindl. \& Nees) Steud., previously known only from South America, is recorded here for southeastern United States, Mexico and Central America. A description of the species is presented, as well as a key to separate E. obtusetrigona from other robust species of subgenus Limnochloa with which it has been confused.
\end{abstract}

Key words: Central America, Cyperaceae, distribution, Eleocharis, Mexico, new record, U.S.A.

\section{RESUMEN}

Eleocharis obtusetrigona (Lindl. \& Nees) Steud., conocido previamente de Sudamérica, es registrado aquí para el sureste de los Estados Unidos, México y Centroamérica. Se presenta una descripción de la especie, así como una clave para especies robustas de Eleocharis subgénero Limnochloa con las cuales E. obtusetrigona ha sido confundida.

Palabras clave: Centroamérica, Cyperaceae, distribución, Eleocharis, México, nuevo registro, Estados Unidos de América.

During the preparation of the treatment of Eleocharis subgenus Limnochloa (Cyperaceae) for the Flora of North America project we discovered several collections of a species not previously recorded for the area. Some of those collections had been identified as E. fistulosa (Poiret) Link, an illegitimate name for E. fistulosa (Poiret) Schult. in Roem. \& Schult., which is a synonym of E. acutangula (Roxb.) Schult. in Roem. \& Schult. 
Eleocharis acutangula is a common species in tropical America. Two of those collections were the bases on which E. fistulosa was cited from North America by Svenson (1957) and Correll \& Correll (1975). However, these specimens differ from E. acutangula in several characters and belong instead to E. obtusetrigona (Lindl. \& Nees) Steudel, which has previously been known only from South America. They are the first record of $E$. obtusetrigona for North America. Other collections of $E$. obtusetrigona which have been misdetermined as E. fistulosa, E. cellulosa Torr. and E. quadrangulata (Michx.) Roem. \& Schult. are known from Mexico and Central America.

Eleocharis is a widely distributed genus of about 200 species. Eleocharis obtusetrigona belongs to Eleocharis subgenus Limnochloa (P. Beauv. ex T. Lestib.) Torr. (Ann. Lyceum Nat. Hist. New York 3: 296. 1836), which is equivalent to E. ser. Mutatae Svenson (Rhodora 31: 127. 1929). The main center of diversity of E. subgenus Limnochloa is tropical South America where 10 species are known (González Elizondo \& Tena, 2000), with secondary centers in eastern North America and in Mexico.

Svenson (1939) placed E. obtusetrigona in E. fistulosa (E. acutangula). Clarke (1898) reduced it to E. mutata var. obtusetrigona (Steudel) Clarke, and Barros (1960) treated it as E. fistulosa var. obtusetrigona (Steudel) Barros. However, E. obtusetrigona can be separated by the cross-section shape of the culms, which are subterete or obscurely angled in E. obtusetrigona and sharply triangular in E. acutangula and E. mutata. Also, in general terms the glumes and achenes are larger in E. obtusetrigona, and the colour of the sheaths is proximally stramineous to pale rose, distally orange-reddish, salmon-coloured or purple in that species, and stramineous to brown or purple in $E$. acutangula and E. mutata. Plants of Eleocharis obtusetrigona have also been misidentified as E. cellulosa Torr. and E. quadrangulata (Michx.) Roem. \& Schult. The following key distinguishes these species.

1 Culms terete or obscurely 3-5-angled; sheaths distally orange-reddish, salmon-coloured or purple; achene with 10-24 rows of cells each face

2 Achene with a stout, spongy thickening at the summit; tubercle $0.1-0.5 \times 0.2-0.5 \mathrm{~mm}$, confluent with or gradually merging from the summit of the achene; bristles smooth or finelly spinulous; floral scales broadly obovate to suborbicular ......... E. cellulosa

2 Achene with a narrow, short neck at the summit or the neck obscure; tubercle 0.8$1.1 \times 0.7-0.9 \mathrm{~mm}$, not confluent with nor gradually merging from the summit of the achene; bristles usually coarsely spinulous; floral scales ovate to oblong

E. obtusetrigona

1 Culms acutely 3 or 4-angled; sheaths distally stramineous, brown or purple; achene with 11-38 rows of cells each face

3 Culms acutely 4-angled; achene with 19-38 rows of cells each face to almost smooth E. quadrangulata

3 Culms acutely 3-angled; achene with 11-32 rows of cells each face 4

4 Floral scales ovate to oblong, coarsely nerved; achene with 11-15 rows of cells each face; tubercle proximally wider than the summit of the achene

4 Floral scales obovate to broadly suborbicular, finely nerved; achene with (16)2432 rows of cells each face; tubercle confluent with or gradually merging from the summit of the achene E. mutata 
Eleocharis obtusetrigona (Lindl. \& Nees) Steud., Syn. pl. glumac. 2: 80. 1854. Limnochloa obtusetrigona Lindl. \& Nees, in Mart. FI. Bras. ii. 100. 1842; Eleocharis mutata (L.) Roem. \& Schult. var. obtusetrigona (Lindl. \& Nees) Clarke, Bull. Herb. Boiss. 6 (Append. 1): 20. 1898; Eleocharis fistulosa (Poiret) Schult. in Roem. \& Schult. var. obtusetrigona (Lindl. \& Nees) M. Barros, Sellowia 12: 262. 1960.- Type: Brasil, Bahia, Salzmann in hb. Lindley (CGE). Eleocharis strobilacea Pedersen. Darwiniana 12(2): 243. 1961.- Type: Argentina, Prov. Corrientes, Pedersen 957 (C).

Perennial plants $40-110 \mathrm{~cm}$. Rhizomes (often lacking in herbarium specimens) horizontal, creeping, 3-4 mm thick, soft to hard; longer internodes ca. $3-8 \mathrm{~cm}$, reddish brown, smooth or slightly sulcate; tubers absent. Culms obscurely 3-5-angled to terete; 3.6$7.5 \mathrm{~mm}$ wide, or as narrow as $2 \mathrm{~mm}$ at the apex; soft; not septate, internally spongy, transverse septa incomplete. Distal leaf sheaths persistent, proximal leaf sheaths sometimes decaying, membranous, proximally stramineous to pale rose, distally orange-reddish, salmon-coloured or purple, sometimes open on the ventral side, distal sheath summit brownish or reddish to purple, often hyaline, not inflate or slightly inflate, oblique (angle as seen from the side ca. 45-75 deg. to the horizontal), acute to long acuminate, sometimes prolonged into a blade-like portion to $6 \mathrm{~cm}$. Spikelets about 1.21.5 times wider than culm, cylindric to ovate, terete in cross section, obtuse to acute; 12 $43 \times 3.5-6 \mathrm{~mm}$; proximal scale without a flower, amplexicaul, 3.6-7.5 mm, appearing to be a continuation of the culm. Floral scales ca. 30-125, ca. 25-36 per cm of rachilla, subappressed at the base, spiraled, deciduous, 4.3-5.8 $\times 2.5-3.3 \mathrm{~mm}$, ovate to oblong; cartilaginous, often membranous toward margins; midnerve scarcely differentiated from the numerous, closely spaced and raised lateral nerves, midrib region nearly flat, greenish to pale brown or grayish, often with a submarginal reddish band or a subapical darker spot; flanks lighter, whitish to pale flesh-coloured, apices rounded to acute, 0.1-0.5 mm, colourless and hyaline, easily torn, margins broadly membranous-hyaline, colourless or pale brown. Perianth bristles ca. 6-7; stramineous with margins and spinules reddish to pale brown; stout, flattened; subequal, exceeding achene, 2.5-3.2 mm; coarsely retrorsely spinulose (rarely with delicate teeth), the spinules about $0.1 \mathrm{~mm}$ long. Anthers reddish brown, 1.5-1.9 x ca $0.2 \mathrm{~mm}$, apex apiculate. Styles trifid (sometimes bifid?), puberulent. Tubercles stramineous to yellow-brown; lamelliform to high-pyramidal, sometimes spongy; 0.8-1.1 x 0.7-0.9 mm. Achenes stramineous often ripening to pale brown or greenish, shiny; obpyriform; biconvex; summit often constricted into a neck 0.5-0.6 mm wide, or the neck reduced and inconspicuous; $1.7-3 \times(1-) 1.2-1.5 \mathrm{~mm}$; at 10-15 times magnification clearly sculptured, each face with 10-18 rows of transversely elongated cells, often isodiametric at achene base.

Eleocharis obtusetrigona is known from southeastern Texas, eastern Mexico, Central America and eastern South America. In Texas it forms large colonies in water in sites where water stands throughout the year at elevations of 0-20 m. In Mexico and Central America it grows up to $1200 \mathrm{~m}$, in fresh permanent water in ditches, pools of standing water and border of roads. Flowering late winter to fall, fruiting spring to fall.

Although locally abundant and forming clonal masses, it is very local in North and Central America, but is more widely distributed in eastern Brazil and northern Argentina 
and Paraguay (Barros, 1960; Pedersen, 1961). This kind of disjunct distribution suggests that $E$. obtusetrigona has been introduced from South America by several events (not necessarily recent) of long-distance dispersal. A more disjunct distribution between southeastern Texas and northern Argentina and Paraguay was reported by Guaglianone \& Ueno (1990) for Eleocharis cylindrica Buckley.

Eleocharis obtusetrigona is known from North and Central America from the following collections:

U.S.A., Texas: Cameron County, Laguna Atascosa National Wildlife Refuge, ca. 0.9 mi S of entrance, near main road, in water, 23-04-1959, A. Traverse 1060 (TEX); Cameron County, four miles east of Rio Hondo, 8-02-1934, E. U. Clover 1752 (MICH, TEX); Brownsville, south of Armstrong, in Kennedy County near highway 96, large colonies in shallow water, 17-10-1938, R. Runyon 1953 (TEX); Brownsville, 20 miles North of Brownsville, bordering the Paredes road, wet ground, ditches, etc., it forms large colonies, 16-06-1941, R. Runyon 2765 (TEX); Brownsville, 20 miles North of Brownsville, on the Paredes road, in ditches where water stands through year, it forms large colonies in water, 6-04-1944, R. Runyon 3680 (TEX).

MEXICO, Veracruz: Miradores, municipio de Dos Ríos, 14-10-1974, F. Ventura 10639 (CIIDIR, ENCB-2); Rancho de la Secretaría de Salubridad y Asistencia (antes Rancho Tres Pasos), municipio de Emiliano Zapata, 19³2' N, 9650' W, 15-04-1977, $R$. V. Ortega 673 (IEB, MEXU).

HONDURAS: vicinity Agua Amarilla and Hoya Grande, Depto. Fco. Morazán, 2710-1989, "tul", A. Molina 34176 (MEXU).

COSTA RICA: Laguna Cóncavas, Prov. Cártago, Cantón Paraíso, 22-08-1983, A. Lot y $A$. Novelo 1214 bis con $R$. Soto (MEXU).

NICARAGUA: Estelí, along carretera Norte, 11 km north of Estelí, 13-08-1978, $P$. C. Vincelli 858 (CIIDIR, MEXU, MO).

\section{ACKNOWLEDGEMENTS}

Thanks are given to the late Dr. T. M. Pedersen for sharing his expertise regarding the variation and distribution of E. obtusetrigona in South America; to Dr. A. A. Reznicek, M.C. Eleazar Carranza, Dr. P. M. Peterson, and two anonymous reviewers for comments; and to the curators of CIIDIR, ENCB, IEB, MEXU, MICH, MO, NY and TEX/LL herbariums for loans of specimens. M. González and S. González acknowledge to CGPI, COFAA and EDI of the Instituto Politécnico Nacional for support for research.

\section{LITERATURE CITED}

Barros, M. 1960. Las ciperáceas del estado de Santa Catalina. Sellowia 12: 262. 1960.

Clarke, C. B. 1898 in Bull. Herb. Boiss. 6. Append 1: 20.

Correll, D. S. \& H. B. Correll. 1975. Aquatic and wetland plants of southwestern United States. Vol. I. Stanford University Press. Stanford, California. 856 pp. 
González-Elizondo, M. S. \& J. A. Tena. 2000. Eleocharis (Cyperaceae) in the New World. In: Wilson, K. L. \& D. A. Morrison (eds.). Monocots: systematics and evolution. CSIRO Publishing. Australia. pp. 637-643.

Guaglianone, E. R. \& O. Ueno. 1990. A disjunct species of Eleocharis (Cyperaceae). Darwiniana 30: 223-229.

Pedersen, T. M. 1961. Nota sobre las especies argentinas de Heleocharis, subgen. Limnochloa (Nees) C. B. Clarke (Series Mutatae, Svenson). Darwiniana 12(2): 241-246.

Svenson, H. K. 1939. Monographic studies in the genus Eleocharis. Rhodora 41: 4-19.

Svenson, H. K. 1957. Eleocharis (Cyperaceae). N. Amer. Fl. 18: 509-540. 